ment does not assert that teaching is one of the institution's central aims? We suggest that all $\mathrm{PhD}$-degree holders who applies for a faculty position in a basic science department at any of this country's medical schools should be required to read the institution's mission statement and attest to their awareness and understanding of the importance of its educational mission.

It is in the best interest of basic science faculty at our nation's medical schools to reassess their commitment to education, especially in light of the financial pressures the schools face. We suspect that one day soon medical school administrators, trustees, and regents, or legislators at the federal and state level, are going to make the same kind of calculation we have made and conclude that they are not getting their money's worth from basic scientists when it comes to their commitment to teaching. Perhaps a wise first step for basic science faculty would be to refrain from using the words "burden" and "protection" when discussing teaching and education, as their jobs could be given to less costly, itinerant basic science educators.

Robert H. Glew, PhD

William Anderson, PhD

Department of Biochemistry and

Molecular Biology

University of New Mexico School of

Medicine

Albuquerque, New Mexico

\section{FATAL APLASTIC ANEMIA DURING TREATMENT WITH KETOCONAZOLE}

\section{To the Editor:}

Ketoconazole is a broad-spectrum, synthetic antifungal agent that impairs the synthesis of ergosterol, a vital component of fungal cell membranes. The most frequent adverse reactions associated with ketoconazole treatment are nausea or vomiting, abdominal pain, and pruritus. Other side effects, noted in less than $1 \%$ of patients, include headache, dizziness, somnolence, fever and chills, photophobia, diarrhea, gynecomastia, and impotence (1). Oligospermia (2) and hepatotoxicity (3) also have been reported. We report a case of aplastic anemia in a previously healthy young woman taking ketoconazole for vaginal discharge.

A 23-year-old woman was admitted with widespread purpuric lesions on her face, arms, and legs. Her hemoglobin level was $10.9 \mathrm{~g} / \mathrm{dL}$. She had a red blood cell count of $4.0 \times 10^{6}$ cells per $\mu \mathrm{L}$, a platelet count of $9.0 \times 10^{3}$ cells per $\mu \mathrm{L}$, and a white blood cell count of $5.5 \times 10^{3}$ cells per $\mu \mathrm{L}$ (neutrophils $35 \%$, lymphocytes $64 \%$, monocytes $1 \%)$. She had taken ketoconazole (200 mg twice daily; Ketoral; Bilim Ilac, Istanbul, Turkey) for vaginal discharge for 4 days before admission. She denied any other drug use. Ketoconazole was stopped on admission.

A bone marrow aspiration and biopsy specimen obtained on the second hospital day revealed poor cellularity (but no fibrosis), megakaryocytic aplasia, severe depression of the myeloid series, moderate depression of the erythrocytic series, and plasmacytosis. Amyloidosis was ruled out by bone marrow preparations stained with Congo red. The pathologist noted cytoplasmic vacuolization and dyspoiesis, which was thought to be caused by toxic injury to the bone marrow.

Seven days after admission, the patient's white blood cell and erythrocyte counts dropped progressively, and she developed pancytopenia. There was no evidence of an autoimmune disorder and no history of a viral infection. Liver and kidney function tests yielded normal results. An ultrasonographic examination did not reveal splenomegaly or lymphadenopathy. Tests for parvovirus B19 (immunoglobulin M $[\operatorname{IgM}]$ ), cytomegalovirus (IgM and IgG), EpsteinBarr virus (IgM), serum antibodies to hepatitis B surface and core antigens, hepatitis C virus, and paroxysmal nocturnal hemoglobinuria all yielded negative results. In addition, hepatitis $B$ surface and e antigens were not detected in the serum.
Based on these findings, the patient was diagnosed with aplastic anemia, as defined by Gordon-Smith and Lewis (4). She was given platelet and erythrocyte transfusions when indicated. One month after hospitalization, owing to persistent symptomatic illness, we administered a treatment protocol composed of daily treatment with antilymphocyte-globulin $(15 \mathrm{mg} / \mathrm{kg}$ intravenously), methyl prednisolone $(2 \mathrm{mg} / \mathrm{kg}$ intravenously), cyclosporine-A $(5 \mathrm{mg} / \mathrm{kg}$ orally), and granulocyte colony-stimulating factor $(5 \mu \mathrm{g} / \mathrm{kg}$ subcutaneously). She did not respond to the therapy and died of disseminated candidiasis 2 months later.

Hematologic side effects related to ketoconazole are uncommon. Ketoconazole-associated leukopenia, thrombocytopenia, and hemolytic anemia have been reported (5). In our patient, the sudden onset of pancytopenia after taking ketoconazole and the lack of any other possible cause suggest that this drug may be responsible for her bone marrow failure. Her illness seemed to be an idiosyncratic reaction, unrelated to cumulative dose or duration of administration.

We hope that this report, and others like it, will contribute to future patient care.

Dursun Duman, $M D$

Nazim S. Turhal, MD

Deniz G. Duman, MD

Department of Internal Medicine Marmara University Medical School Istanbul, Turkey

1. Terrell LC. Antifungal agents. Part II: the azoles. Mayo Clin Proc. 1999;74:78-100.

2. Eil C. Ketoconazole binds to the human androgen receptor. Horm Metab Res. 1992;24: 367-370.

3. Bernudu J, Durand F, Pessayre D. Ketoconazole-induced hepatotoxicity. Hepatology. 1997;26:802.

4. Gordon-Smith EC, Lewis SM. Aplastic anemia and other types of bone marrow failure. In: Hoffbrand AV, Lewis SM, Tuddenham EGD, eds. Postgraduate Haematology. 4th ed. Butterworth-Heinemann: Oxford; 1999: 68-90.

5. Nizoral (Ketoconazole), adverse reactions. In: Physicians Desk Reference. 55th ed. Montvale, NJ: Medical Economics Company; 2001:1580. 